frequency Phase and Amplitude Characteristics of Television Receivers"; Marconi Premium to Prof. P. M. Honnell (Washington University, St. Louis), for his paper, "Prescribed-Function Vibration Generator" ; Dr. Norman Partridge Memorial Award to H. J.' Leak for his paper, "High Fidelity Loudspeakers : the Performance of Moving Coil and Electrostatic Transducers".

\section{Gas Council Research Scholarships}

THE Gas Council has awarded research scholarships to the following students who have recently graduated in physics, chemistry or engineering: A. Richmond (University of Oxford, Department of Inorganic and Physical Chemistry), the mechanism of gaseous oxidation processes; K. J. Reid (University of Cambridge, Department of Chemical Engineering), chemical engineering fundamentals; P. Hawtin (University College, London, Department of Chemical Engineering), heat transfer with a special interest in heat transfer to gases; D. Wilson (University of Birmingham, Department of Chemical Engineering), gas absorption; J. N. Sherwood (University of Glasgow, Department of Chemistry), diffusion studies in molecular crystals.

\section{National Vegetable Research Station Association}

THe National Vegetable Research Station at Wellesbourne, Warwick, is proposing to form a National Vegetable Research Station Association. The Research Station welcomes contacts with growers. It already owes much to those growers who have assisted in its establishment and subsequent development. The Association is being set up to advance the knowledge, science and practice of vegetable production. Any member (grower or other interested person or firm) will be able to keep in touch with the latest research developments at the Station. He will receive copies of the Station's annual reports and will have the privilege of attending members' days. These days will provide opportunities for the interchange of ideas between research workers and growers, and will enable members to see and discuss work being done at the Station, to keep themselves abreast of the latest progress, and to meet other growers with common interests. Further information can be obtained from the Secretary, National Vegetable Research Station, Wellesbourne, Warwick.

\section{Advice on Careers}

Alтнолgh the Youth Employment Service is performing a useful service in helping school-leavers to find and settle down in the right jobs, the schools have still an important part to play in helping scholars to decide on the kind of career which would be most suited to them. Many teachers are regrettably ill-equipped to give vocational advice, and, to help them, the National Union of Teachers has produced a useful pamphlet. Besides the many advertisements by business, industrial and other organizations - the value of which is open to question - the pamphlet contains a number of notes and articles which are both practical and up to date and should be of considerable assistance to careers masters and mistresses. These include such topics as the employer's expectations from the applicant, the essentials of apprenticeship schemes, universities and admission procedure, the role of the trade unions, careers for girls, selection procedure in industry and commerce and many others. The pamphlet contains exhaustive lists of valuable addresses. Copies can be obtained from the National Union of Teachers, Hamilton House, Mabledon Place, London, W.C.1.

\section{Nature Reserves}

Fonty years after its founding, the Society for the Promotion of Nature Reserves has been taking stock. Despite the advent of the Nature Conservancy, the number of inquiries received during 1956-57 from other organizations and individuals interested in the acquisition of Nature reserves shows that the Society still performs an important function. In respect of at least seven of the inquiries discussions are still continuing with interested local individuals and organizations to see whether certain areas can be designated as Nature reserves. The fortieth annual report contains details of how existing Nature reserves are being managed and developed; these vary from Badgeworth Marsh in Gloucestershire, which was acquired solely to protect the very local buttercup, Ranunculus ophioglossifolius, to Scotton Common Nature Reserve in Lincolnshire, an area of about forty acres and one of the best of the few remaining tracts of blown-sand heathland in north-west Lincolnshire. Details of all the business transacted by the Society during 1956-57 are contained in the report, which may be obtained from the Society, British Museum (Natural History), London, S.W.7, price $5 s$.

\section{Instrumentation for Gas Chromatography}

THE Scott microflame detector has now been made available commercially for gas chromatography (Shandon Scientific Co., Ltd., 6 Cromwell Place, London, S.W.7). This novel detector (Scott, R. P. W., "A New Detector for Vapour Phase Partition Chromatography"; see "Vapour Phase Chromatography", edited by D. H. Desty, p. 131 ; Butterworth, 1957) depends on the use of a carrier gas containing a considerable proportion of hydrogen, which is burnt in a small flame near the column exit. The presence of an organic vapour in the gas increases the length of the flame, and this results in a comparatively large response from a thermocouple situated just above the normal flame. The advantages of this detector are that it has an extremely small effective volume, resulting in a very rapid response; and secondly, that its response is directly proportional to the calorific value of the vapour; which means that in the analysis of hydrocarbons, calibration of the detector for individual compounds is unnecessary.

\section{A New Submarine Mountain in the Pacific Ocean}

A submarine mountain $\left(31^{\circ} 34 \cdot 7^{\prime} \mathrm{N} ., 131^{\circ} 08^{\prime} \mathrm{E}\right.$.), named after Prof. T. S. Isakov, was discovered by the U.S.S.R. Expedition S.S. Vityaz on September 27, 1955 (Sergeev, I. V., and Udintzev, G. B., Doklady Akad. Nauk., S.S.S.R., 113, 1123; 1957). This mountain rests on a $5,000 \mathrm{~m}$. platform and its top is situated at the depth of $1,400 \mathrm{~m}$. Its cone-shaped form and the dredged fragments of volcanic rocks suggest a volcano.

\section{Silvina Estrada de Acevedo Fellowship for Research in Experimental Leukæmia}

TrIs fellowship, instituted by Don Horacio Acevedo in memory of his wife, for furthering research in experimental leuk»mia, is open to scientists from any 